\title{
Plugging into the Umbra: Creative experimentation (in)(on) the boundaries of knowledge production in ECEC research
}

Nikki Fairchild

University of Chichester n.fairchild@chi.ac.uk

\section{Abstract}

Research into Early Childhood Education and Care (ECEC) policy and practice in the UK is subject to the demand that such research be measurable and achieve impact to provide the basis for evidence-based professional practice. New and creative experimental ways of knowing/thinking/doing ECEC research have been proposed in resistance to this quantified and instrumentalised agenda. Here I focus on posthumanist theorising, which proposes research that does not privilege the human subject but rather opens conditions of possibility for an entanglement with non-human and more-than-human bodies within and between assemblages. This engagement with complexity is a new ethical and political project aiming at re-conceptualising ontology beyond the limits of the human. Posthumanist research does not only challenge quantitative research, but also engages creative ways to challenge the limits of qualitative inquiry. Drawing on my research experience, I explore this de-centring of the human-as-researcher through the notion of the 'methodological umbra'. This shadow space is one in which traditional thoughts on research open out these new forms of inquiry into thinking-in-movement. My analysis uses my own diary entries as sites in which this 'umbra' becomes evident under the pressure of creating new forms of a 'living' methodology. This is analysed through the contrast between smooth and striated space proposed by Deleuze and Guattari (1987) to explore what form of life might emerge in the smooth space of the umbra.

Keywords: Methodological umbra, ECEC research, posthumanist theorising, post-qualitative inquiry, smooth space, striated space, assemblages.

\section{Introduction}

We are in a period of continuous change and uncertainty within the field of Early Childhood Education and Care (ECEC), as successive Governments consider the value of quality ECEC as a precursor to formal compulsory education. This is exemplified in England with a plethora of policy changes which frames the child and the Early Years Teacher (DfE, 2013) as central to economic regeneration, where introducing rigour into curricula frameworks (DfE, 2014) and teacher training are hailed as the panacea for wider social issues (Waldfogel, 2004; Bertram and Pascal, 2014). It is within this context that the conceptualisation of ECEC research takes a number of, what Deleuze and Guattari (1987) would call, striated forms where processes and normalised ideas of research practice can set limits of the purpose and value of research and researchers modulate their practice to fit 
these dominant normative ways. In a short paper Deleuze (1992) considered how power circulates in modern societies via perpetual training where individuals strive to enhance their skills via continuous modulations of self. These modulations form controls, which are exemplified by continually changing self-regulatory processes where ephemerality and flexibility shape bodies. Within ECEC modulations are revealed where the changes in policy expectations, such as increasing levels of workforce professionalization and early intervention, impact on practice (Bertram and Pascal, 2014). The call for evidence based practice by policy makers and research funders expect research to focus on 'what works' in ECEC settings and classrooms to enhance professional practice and promotes this idea of perpetual training and modulations (Deleuze, 1992) for both children and ECEC practitioners.

This reliance on evidence-based policy making and practice has been the subject of debate and critique, which has argued that this mode of research promotes hegemony and seeks to control democratic participation in education (for example, Biesta, 2007). In parallel there have been discussions surrounding the rationale and purpose of ECEC (Moss, 2014), a critique of common sense notions of practice (Dahlberg et al, 2013), professionalism (Osgood, 2012), and quality (Jones et al., 2016). Problematizing ECEC policy and practice has seen the emergence of a movement, which searches for a more democratic approach to ECEC. For example, scholars belonging to groups such as 'Reconceptualising Early Childhood Education' have postulated and generated debate into alternative ways of seeing/doing/being an ECEC researcher and/or practitioner (Bloch et al., 2014).

Intervening in this debate, I want to consider how posthumanist theorising and thinking can unsettle the usual forms of ECEC research. Posthumanist theorising is premised on the concept of a flat ontology where no one entity holds a position of ontological centrality. The term flat ontology was derived from the work of DeLanda (2002) who drew on Deleuze when he considered that there was no primacy of nature (humans) over the non-human or more-than-human world. Collapsing these binaries allows for an exploration of the connectivity and complexity of the inter-relationships between human and non-human/more-than-human bodies. Here the 'post' does not denote a replacement for humanism, more an acknowledgement that a wider philosophical position is needed to consider these relational entanglements. For some, this engagement draws in new material dimensions, which consider human and material subjectivities positioning a new ontology of the material (Coole and Frost, 2010). Additionally, new materialists such as Barad (2007) and Bennett (2010) have discussed how matter has its own vitality, which leads to ascribing agency to material phenomena. Posthumanist theorising has moved the democratic and reconceptualising debates forward to consider life beyond solely human notions of mastery, power and privilege.

In the context of educational research, Carlson has argued that posthumanist theorising:

calls for forms of democratic education, curriculum, and pedagogy that deconstruct the common sense, taken-for-granted naturalness of humanism, not from an anti-humanist perspective, but as a movement beyond the limits and contradictions of the humanist project while still maintaining the modernist and humanist projects of rights, justice, equity and freedom. (Carlson, 2015: x).

This widening of the field of research can be developed as a critical approach to the tendency of ECEC policy to take a more technicist approach to professional practice and constructing what it means to be a practitioner. In this context, research in ECEC becomes clearly defined by the need to improve measurable outcomes and to monitor children's progress towards measureable goals (DfE, 2014). These requirements seek to foreclose different ways of seeing/thinking/doing/feeling ECEC. To counter these approaches Snaza and Weaver suggest that: 'educational stories could benefit from more wonder' (2015: 7). To stimulate wonder it is important to question how disruptions to the subject-object relationship could produce new ways to think ECEC. A commitment to posthumanism is not only driven by a critique of the prevailing order but also by what Snaza and 
Weaver (2015: 10) call 'a radical commitment to experimenting with the new, unpredictable, perhaps seemingly impossible forms of relations'.

In a similar way to how the 'posts' in philosophy representing a move beyond certain philosophical world views, the 'posts' in research seek to do the same (St. Pierre, 2013). Post-qualitative research has emerged as a means to disrupt current research practices and to challenge representations of being, truth, and absolute knowledge (St. Pierre et al., 2016). It can be seen as a response to the view that qualitative research had become more mechanistic, following structures and normalised processes of research. In an interview, St. Pierre suggests that qualitative research, originally formulated as a response to positivist social science, 'has become more predicative, like positivist social science' (Guttorm et al., 2015). Furthermore, MacLure (2011) has questioned how successful researchers have been in putting theory to work in qualitative research, and argued that a move to post-qualitative inquiry is an ethical, political, and methodological project. Lather and St. Pierre concur when they discuss 'the ethical charge of our work as inquirers is surely to question our attachments which keep us from thinking and living differently' (2013: 632). Post-qualitative inquiry has developed to consider the possibilities of the ontological (re)turn of inquiry, which envelops the human and material world in co-constitutive relations rather than as a binary opposition (St. Pierre et al., 2016). These new ways of conceptualising research have questioned whether existing knowledge practices of methodology and method are found lacking when research is concerned with de-centring humans in the research process (Taylor and Hughes, 2016; St. Pierre, 2016a). Jackson and Mazzei have explored ways of plugging theory into inquiry and suggest this approach 'illustrates how knowledge is opened up and proliferated rather than foreclosed and simplified' (2013: 261).

This paper draws on my entanglements with methodology experienced as part of my doctoral research inquiry. The primary material is my own diary entries, which I want to probe as sites (not only of self-reflection, which might risk a narcissistic reinforcing of the human subject) as a means of opening to the 'methodological umbra'. This 'umbra' is a shadow space of connections and activations, human and non-human, which criss-cross the experience of research. Part of the umbra is the connections of a flat ontology and to that of knowledge production. In this paper I, as human, am documenting the development of $(a)(m y)$ post-qualitative inquiry. By de-centring myself, I attempt to overcome the position of researcher as transcendent body and reconceptualise the researcher as part of the flat ontology making connections with theory, methodology, method and data. St. Pierre (2016b) offers us a provocation when she discusses that traditional notions of epistemology and ontology do not fit with new research practices as they are always-already saturated with assumptions about how knowledge is produced/created. She considers 'The idea that theory and practice are inseparable - one might write them together as theorypractice - and material as well, is crucial in the new empiricism' (St. Pierre, 2016b). Furthermore, she suggests that as humans we are no longer the central point of any inquiry as the knowing subject, epistemology is no longer an adequate response to what she entitles 'New Empiricisms'. Using the concepts of smooth and striated space from Deleuze and Guattari (1987), which contrast the striated space of organisation and order to an anarchic smooth space, I suggest that this umbra is the shadow of a smooth space that disrupts the striations of conventional research, quantitative and qualitative. It is out of this shadowy zone that new forms of vitality and interconnection emerge, positing a new form of posthuman inquiry.

\section{Striated, Smooth and Shadow Spaces}

When thinking/working/feeling posthuman inquiry there are a number of concepts, which can activate movement-in-thinking (Massumi, 2002; Manning, 2013; Springgay, 2015). Deleuze and Guattari (1987: 444) consider that 'movement designates the relative characters of a body...speed...constitutes the absolute character of a body'. They also consider how movement can 
be fast but that may not give a body speed and speed can be slow or immovable but it is still speed. Furthermore, Manning (2007) sees movement as relative or absolute, where relative movement sees bodies separate from the inhabited space, moving from point to point unchanging as they move. With absolute movement, the body exists in movement, endlessly differentiating as bodies are noted 'in space time and time space rather than existing in an empty container of space marked by the passing of linear time' (Manning, 2007: xvii). These differentiations, or becomings, are where bodies collide and connect with each other where the connection point is indiscernible. Here it becomes impossible to say where the boundary lies between the two bodies as they share characteristics with each other (Deleuze and Guattari, 1987). In Essays: Critical and Clinical Deleuze (1997) exemplified the notion of becoming when he discussed the struggle of Captain Ahab and the Great White Whale in Moby-Dick. Becoming-whale was the point where Ahab and Moby-Dick enter a zone of indiscernibility where they both 'lose their texture as subjects in favour of "an infinitely proliferating patchwork" of affects and percepts that escape their form' (Smith, 1997: xxx). It is at the zone of indiscernibility, this point of becoming, that differentiating bodies produce pure movements, which are revealed within the spaces between connecting bodies.

When Deleuze (1994) asked the question 'how might one live?' he drew on Spinoza (May, 2005) to consider 'what might a body be capable of'. Here, the term life does not only consider a corporeal body but also the connections and relations between non-human and more-than-human bodies. Deleuze and Guattari refer to 'life' in a range of ways; there are organisms - 'complex systems of stratification' (Deleuze and Guattari, 1987: 391) which exist within and between assemblages. There are also examples of non-organic life, which can be subject to non-human becomings (Deleuze and Guattari, 1987; Bonta and Protevi, 2004). Furthermore, the term body describes a more than corporeal body, it could be drawn from the non-human or more-than-human for example it could include 'a body of work, a social body or collectivity, a linguistic corpus, a political party, or even an idea' (Baugh, 2010: 35). Affect describes the potential of the body and how this interacts, interconnects and changes other bodies as connections are made, dropped, and remade within an assemblage (Deleuze and Guattari, 1987; Ross, 2010). An assemblage details the collection of relations which develop around actions and events (Fox and Alldred, 2015). Livesey discusses how assemblages are a 'complex constellations of objects, bodies, expressions, qualities and territories' (2010: 18). Here Deleuze and Guattari suggest (1987) the assemblage can be drawn from the social, cultural, material, political, and discursive and have an existence independent of human bodies. The assemblage becomes machinic as it creates and is created by virtue of its connections with other assemblages. In a fluid and dynamic way, assemblages connect and plug into the machinic assemblage to form new assemblages, which then connect and plug into other machines as part of ongoing relational entanglements and becomings (Deleuze and Guattari 1987; Jackson and Mazzei, 2012).

Deleuze and Guattari (1987) in A Thousand Plateaus used space as a means to explore the relationship between the State and individuals. They detail smooth and striated space as fundamentally different but inter-related and co-constitutive. Smooth space is occupied by intensities and events and is surrounded by striated space and vice versa 'smooth space is constantly being translated, transversed by striated space; striated space is constantly being reversed, returned to smooth space' (Deleuze and Guattari, 1987: 552). They go on to discuss that smooth space is ephemeral, which means it has no memory and as such can only ever hold microhistories, microsociology and micropolitics which allows it to be a site for transformation and possibility. By contrast striated space is a stable system and the product of stratification, especially by mechanisms such as the State. Both humans and non-humans can striate space but humans have become very adept at using signifying regimes to striate the space very effectively. This is achieved by over-coding concepts, ideas or structures producing hierarchies, binary opposites and segmentation. Deleuze and Guattari warn that smooth and striated spaces are not binary opposites but are positions, which reflect the vital nature of relational entanglements with bodies. They are particularly interested in 
the tensions between smooth and striated space when they consider 'how the forces at work within the space continually striate it, and how in the course of its striation it develops other forces and emits new smooth spaces' (Deleuze and Guattari, 1987: 581).

Working with posthuman, post-qualitative inquiry can activate all the concepts described above and I will demonstrate how the fluid interplay and movement within and between them can be revealed when they are plugged in. If we consider Deleuze's perspective on life - a life of immanent, positive, productive connections between bodies in an assemblage (May, 2005) - we can apply this perspective to research to pose different questions within inquiry. When connecting affect and methodology, we might ask 'How might a methodology live?', and it is to this question that I turn next.

\section{In the Shadows}

It is within the context of ECEC research needing an evidence base to be deemed valid that I consider the (im)possibilities of research practices using the 'posts'. Traditional research practices cast an umbra, a methodological shadow when trying to research and think about research differently. Furthermore, the umbra becomes a positive and productive opportunity to open wider conditions of possibility for inquiry, which push the envelope of doing/thinking/exploring research inquiry. Here research can be conceptualized as a 'living' inquiry where relations and connections within the research assemblage of humans, non-humans and more-than-humans can reveal new ways to think and experience inquiry. Working with posthumanism and post-qualitative inquiry provides an opportunity to move away from what Deleuze and Guattari (1987) would call a tracing of research practices for a set aim, for example, the prevalence of evidence-based research and practice in ECEC. In this instance we are urged by Deleuze and Guattari to make a map not a tracing, as the tracing fixes knowledge in what they entitle 'tree logic' where knowledge 'is to describe a de facto state, to maintain balance in intersubjective relations...on the basis of an over-coding structure or supporting axis, something that comes ready-made' (Deleuze and Guattari, 1987: 11-12). They go on to describe the map as a fluid becoming, which allows for unconscious experimentation, in turn promoting and supporting connectivity within assemblages.

The posthumanist turn has started to emerge in ECEC research. For example, scholars such as Olsson (2009), Lenz Taguchi (2010), Jones and Holmes (2014), Otterstad and Waterhouse (2015) and Osgood and Scarlett/Giugni (2015) have employed the work of Deleuze and Guattari and feminist New Materialists, such as Barad (2007), to reveal new entanglements with the non-human and more-than-human world. When embarking on a posthuman, post-qualitative inquiry researchers may seek guidance on the process and procedures of putting concepts to work. It can be a challenge to navigate what has been explored previously and researchers may look for a concrete set of guidelines - a 'how to' of posthuman post-qualitative inquiry. Koro-Ljungberg (2012) details how examples of research practice give terrible power to fix ways of doing/knowing research, which then stand true for all other instances. For each new inquiry there can be no known or predetermined direction; bodies connect within and between assemblages without direction or a-priori knowledge of each other. This means each assemblage is a production of newness and the same connections are never seen again as the assemblage reformed is always different from what it was before. Manning contends (2007: xiii) 'The body does not move into space and time, it creates space and time: there is no space and time before movement'. This can also ring true with regards to posthuman, post-qualitative work - there is nothing prior to the research inquiry and any tracing of methodology/methods only serve to fix and reify the entanglements and seek to foreclose the complexity and movements within and between assemblages.

As a researcher these multiple and complex ways of working with posthumanism and postqualitative inquiry can be conceptualised as 'working in the umbra' with the term umbra 
representing the shadows and traces of new ways of performing/enacting/entangling with research inquiry which are in tension with traditional qualitative research. This can be exemplified in my own work by the vital dialogue between the striated spaces of traditional research practice and the smoother spaces of a posthuman, post-qualitative inquiry. Here I debate the interplay between these conceptual spaces where knowledge and knowing, fluidity in methodological design, data and what it may reveal, and how the methods selected might/might not fulfil my posthuman aims. The challenges of doctoral research when working with posthumanism have been explored, particularly when writing a thesis (Honan and Bright, 2016) or considering knowledge production (Cumming, 2015) and I move these discussions forward as I engage with how methodology is 'living' and productive.

Post-qualitative inquiry is confounded as language seems inadequate when working with a flat ontology, which moves away from representational thinking. Massumi (2015: 170) suggested 'naming is a technique for fixing the procedures, in the sense that you fix a compound' and in posthuman and post-qualitative work language is used differently as concepts named do not always match the traditional definition of the signifier. In The Logic of Sense Deleuze (1990) offered a mechanism to overcome these linguistic challenges by considering how verbs can be used to trouble and unsettle thinking. Koro-Ljungberg (2016: 12) explores research language noting how 'Labels matter, since they serve as epistemological markers, ontological reference points and personal preferences...used to legitimize one's scholarship'. She suggests researchers question terms used within inquiry and work against these to disrupt normative signifiers and produce creativity and 'conceptual movement' (Koro-Ljungberg, 2016: 22). However, researchers can still become stuck and knotted as these concepts/words collide with new and old ways of thinking and doing research.

It is clear that what is produced are more questions about the how and why of research inquiry, and no fixed answers, methodology, or methods which researchers can follow. This should be expected as St. Pierre (2016b: 113) suggests: 'I suspect methodology as we know it is unthinkable in the new empiricisms of this ontological turn'. These thoughts/feelings can leave researchers with a sense of unsettledness and a need to know how to perform posthuman, post-qualitative work. However, being more fully open to the unsettledness and relationality in research assemblages promotes a move past straightforward stories and resists the drive to categorise inquiry. Working within the methodological umbra allows absolute movements, which can be intensified and actualised as researchers become-with-methodology. In my work, the drive to push beyond traditional research strategies has seen an engagement with theory (for example - Jackson and Mazzei, 2013; Snaza and Weaver, 2015; Taylor and Hughes, 2016) to de-centre and unsettle thinking. The product of this unsettledness sees working and experimenting in the middle, as the research inquiry folds and unfolds to reveal becoming-researcher, becoming-methodology, becoming-data. I have demonstrated that the methodological umbra is not just concerned with the shadows of traditional research practice but also with conceptions of knowledge and knowledge production. I will now consider how the umbra was actualised within my doctoral research.

\section{Actualizing research inquiry and the 'New Empiricisms'}

Here I will explore whether it is possible to actualize a posthuman, post-qualitative inquiry as part of a doctoral study where I discuss three aspects: methodology, data and methods. The challenge when working with posthuman theorising is how to develop a methodology, which allows for a de-centring of the human subject including the human-as-researcher. I am mindful that I am part of the research assemblage and that it is a challenging process to de-centre the use of ' $I$ '. It could be questioned whether I am self-reflecting, which is not congruent with the de-centred subject, or reflecting on the self which allows for the de-centring of the human. I draw on Cumming (2015) who overcame this dilemma by reframing her research to consider production and what a body does. She argued that this de-centred both her and her research participants and demonstrated the affective 
interrelationships with other elements of the research assemblage. When considering the questions 'how might a methodology live?' it is important to consider the 'I' as a body enmeshed in the research assemblage. By re-framing the human-as-researcher as a body within the research assemblage it is possible to explore entanglements and connections with other bodies. Here other bodies might include data, the researcher, methods, theory, and methodology. Using the conceptualization of researcher as part of the wider assemblage I have included extracts from my research diary which help to consider the flows of affect within and between bodies in the research assemblage. Theory has been read through data excerpts and irruptions provide a mapping of the development, flux, and flow of the methodological umbra.

My doctoral research explored new understandings of the Early Years Teacher: child couplet which moves away from a human conception of the teacher and child needing education under the lens of neoliberal human capital theory (Moss, 2014). The research sought to offer a provocation to a different way of seeing/doing/feeling/thinking early years teaching, a cartographic mapping of Early Years Teachers relations-in-the-world to reveal a new ethics of entanglement where complexity, movement, affect, bodies, matter and materiality are in constant productive relations with each other. Originally an ethnographic methodology had been proposed for the research inquiry but it soon became clear that this methodological choice might not suit a posthuman, post-qualitative engagement. Taking into consideration the dynamic and vital nature of assemblages it seemed incongruent to plan and trace the methodology and methods. Furthermore, as St. Pierre (2016a, 2016b) suggests, the ideas of a static research aim and questions also became problematic which can impact on how to reconcile the expectations of a research aim and questions as part of a doctoral thesis.

Koro-Ljungberg (2016) argues that a fluid approach to methodological design can aid post-qualitative researchers. Keeping the methodological design open to question can offer researchers a chance to be open to surprise (Koro-Ljungberg and Mazzei, 2012), to resist grand narratives, and be receptive to complexity at the limits of one's knowledge (Koro-Ljungberg, 2016). The fluid approach plugs into the assemblage in flux and prevents the foreclosing of ideas, data, and analysis. The ephemerality of the methodological space removes the need for fixity of methods and the 'methodology without methodology represents methodologies without strict boundaries or normative structures methodologies which may begin anywhere, anytime, but by doing so can create a sense of uncertainty and loss' (Koro-Ljungberg, 2016: 1). The following diary excerpt highlights the nature of the smooth and striated space when opening to a more fluid methodological approach:

[Researchers find] a methodological shadow (umbra) of trying to research and think of research differently. It is an opportunity to move away from a tracing of research practice in ECEC. Thinking a fluid methodology details temporality in the methodological space. It considers my discomfort at data collection (can I even call it that?) without guiding principles. It is somewhat liberating - a unique methodological event pertinent to my research. Not transferrable but ephemeral and shadowy as it blurs the boundaries between method, data and analysis. This is a creative experimentation, a rhizomatic multiplicity non-linear, connective, flatness, and ruptures. How do things work? What does knowledge do and how might it generate more or less life? What does my methodology want? How might it live? How can I unfix agency and recognise the plurality of inter-relationality?

Taylor reflects some of these initial concerns when she suggests 'the larger project of becoming posthuman is fraught with difficulty, just as inventing practices which use posthumanist frames of reference in educational research are contentious' (2016: 9). Within the excerpt it is possible to sense the umbra as a move to smoother space, when the researcher considers the fluid and ephemeral nature of her methodology which remains in tension with surrounding striated space that over-codes traditional research practice. It can be seen that language is working at its limits where 
'tracing research practice' is discussed along with 'data collection'. The counterpoint is revealed when the researcher considers the emergent nature of fluid methodologies and uses language to create movement, for example in the use of the terms 'rhizomatic multiplicity', 'connective' and 'rupture'. The resultant methodological umbra produces more questions and provocations than it resolves.

In this second excerpt, a dialogue between traditional research practice and a more fluid postqualitative inquiry is explored:

I keep getting drawn back to humanist ways of thinking - supervising dissertations, teaching research methods, discussions with colleagues, participation in research seminars all seem to draw me back into the fold to envelop me back to conventional ways of being and knowing. How can I escape from its seductive power? Can I ever truly escape it? There are traces everywhere!!!

There are questions about research and knowledge production. I need to think more widely and draw on Taylor (2016) who suggests research is an act of knowing in being... There are traces of traditional research practices in my work - interviews, observations, diaries, images. Need to be mindful to de-centre the human and of wider engagements with methodology and becoming-with bodies such as space, environment, sensory entanglements, weather, travel (trains, cars, walking, ferries - the journey).

The umbra is working in this extract plugging in to the researcher in multiple ways. The tension is revealed as traditional research practice draws the researcher back to a more humanist way of knowing and thinking. This shadow makes it a challenge to think differently and demonstrates what Jackson and Mazzei (2009:3) entitle a 'paralysis' when faced with limitless choices with regards to research (in the case of their work they were referring to conceptualizations of voice). However, Holbrook and Pourchier (2012) see this paralysis as a site of production as they state 'Paralysis is not stoppage. Instead, paralysis can be conceptualized as a productive site where provocative things happen' (Holbrook and Pourchier, 2012: 42). In the excerpt above, initially paralysis troubles the researcher leaving her smothered and enveloped within the shadows, this becomes mediated as she plugs into theory (in this instance Taylor, 2016) and wider engagements with new bodies becomes possible.

The next pertinent question of any (doctoral) researcher is what kind of data will be collected to substantiate or allow problematization of the research aims. There are texts turned over to the collection, categorization and analysis of data (for example - Cohen et al., 2011; Silverman, 2011) but again these do not recognise the ambitions of posthuman, post-qualitative work which seeks to move away from coding and representing data (MacLure, 2013). The concept of data has been problematised by scholars, for example, Holmes and Jones (2013) discuss how the affective nature of data causes decompositions as it becomes-with other connections in research assemblages. Similarly, Koro-Ljungberg (2013) sees data everywhere, surrounding researchers. This notion moves away from the traditional sense of data, out there waiting to be collected. Benozzo et al. (2013) draw our attention to the ever-changing, partial nature of data and consider how it is affected by movement through research assemblages and St. Pierre (1997) highlights the 'transgressive' nature of data which includes dreams and sensations. The excerpt below engages with the exploration of data:

Have my data converged by chance? Possibly not, this is why posthuman research practice is so difficult. I only had a certain date/time to conduct (?), collect (?), find (?), be ready for (?) data due to the nature of being a part time student. Or were data chance events, actualizations, a coalescence of things/happenings? By just watching life would I have seen 
anything meaningful? Maybe I am too focused on knowledge production. This is where the tension between a PhD (or any research) and posthumanism is revealed.

Have I/am I rethought/rethinking data - I am not sure what data is or what data wants. My thoughts around data could border on sensory ethnography (Pink, 2015) or transgressive data (St. Pierre, 1997) or vital data (Koro-Ljungberg, 2013). Data has become everything I see, feel, smell, touch, taste, hear, experience, travel. I suspect my leaky body (Longhurst, 2001) has/is becoming-with data; I am intra-acting with my data.

This excerpt shows thinking (in)(on) the boundaries of smooth/striated space as the researcher questions how becoming-methodology becoming-data can be actualised in research inquiry. The smooth space, where data can be rethought, is surrounded by striated space where data is collected using methods based on representation and researcher aims. In the final two sentences the researcher notes how the affective intensity has influenced her corporeally. She pays attention to the porosity of her skin and how at a molecular level she is becoming-with the data which is and could be encountered. The shadow of becoming-methodology becoming-data reveals a more emergent view that data could be drawn from multiple aspects of human, non-human and morethan-human worlds.

As originally detailed the researcher had considered an ethnographic approach and had selected a number of methods to support this aim including unstructured interviews, in-depth non-participant observations, participant diaries, visual images, and a researcher diary. The researcher worked with four Early Years Teachers over a six-month period during which a range of data were explored/revealed. It can be seen in the excerpt below that the researcher is concerned about how the seemingly humanist methods of 'collecting data' can be actualised as part of her posthuman, post-qualitative methodology:

How do words, texts, images, fold/unfold into/onto each other? How do these methods modulate the engagements - how does this cause movement of thought?? How can this allow us to think differently?? It is a real struggle to keep pushing past representation in my work with Early Years Teachers as they are so engaged in their own meaning-making when they work with children. How can Bennett's (2010) notion of 'vibrant matter' not foreground the 'use-value' (Holmes and Jones, 2016) of the objects carrying sense and meaning?? Is the human subject (researcher) able to fully account for the vibrant, material, thing-power. How can we open ourselves more fully to relationality in our research. I feel I am back here again...maybe I am stuck here.

Drawing on Holmes and Jones it can be seen that methods can foreclose experimentation when they consider how 'the for-ness and use-value of objects as carriers of sense and meaningful expression' (2006:111) can shape our thinking and acting. Furthermore St. Pierre (2016a) suggests that we need new ways to conceptualize research practice which move beyond current ways of seeing and doing research. The resultant tension is expressed by the researcher as the umbra seeks to cloud and shade her own movement-in-thinking particularly in her empirical work with Early Years Teachers. The affect produced by the inter-relationality between the ECEC practice as sites of meaning making and the researchers explorations of posthuman, post-qualitative inquiry reveal more moments of unsettledness as the researcher feels stuck and paralysed (Jackson and Mazzei, 2009).

Springgay (2015) sees research inquiry as a series of techniques and propositions, which help to reveal both relative and absolute movement between bodies. She considers that new tools for thinking data negate the need for new methods in posthuman inquiry but what is needed is 'new procedures that make felt the unknowability and the unknown' (Springgay, 2015: 86). These concerns are taken up by the researcher in the following excerpt: 
Movement $\rightarrow$ shift in understanding of research practices. Methods control, fix and subjugate data - methods insist there are fixed points between which movement happens. Maybe I need to re-conceptualise methods to deterritorialize them. Interviews, observations, diaries, images all become and encounter, an entanglement, a journeyith data (what does data want - does it want a journey? Does a journey suggest fixity? YES) a relational entanglement with data - what might this look like. A set of encounters where propositions (Springgay, 2105) can fold and unfold and an attention to affect - how might this materialize? An attention to the more-than-human during entanglements e.g. the space, the time, the weather, the journey to the setting, the material encounters, the Dictaphone, the camera, paper, pencils, maps ALL these things are part of the assemblage, intra-acting with each other, differentiating with each other, taking lines of flight. Data is revealed or silenced the cartography is/can only be partial - it is not about naming the contents of the assemblage but about considering what is produced. So my 'methods' have engendered events and encounters in/with spaces. I need to think about Manning (2013:15) where thinking in movement 'to move is to think - with a bodying in act' and Deleuze and Guattari (1987: 41) movement is the 'being of becoming'.

In this dialogue with methods, the researcher is describing one of the characteristics of striated space. Deleuze and Guattari detail 'The smooth and the striated are distinguished first by and inverse relation between the point and the line (in the case of the striated, the line is between two points...)' (1987:559). The researcher considers how methods seek to draw a line between points, to

fix, code and stratify encounters with participants. The methodological space becomes smoothed as the researcher deterritorializes the line between points and starts to think in the middle where intensity and movement are revealed. The affects of becoming-with method has encouraged the researcher to reconsider the scope and conditions of possibility contained within her selected method, unlocking the paralysis described in the previous excerpt. It is in this moment within the shadows that absolute movement of thought can be revealed; where the zone of indiscernibility between the researcher and methods has activated a new conceptualization of the research assemblage and it can be seen that 'there are only haecceities, affects, subjectless individuations that constitute collective assemblages' (Deleuze and Guattari, 1987: 310). For the researcher the assemblage includes human, non-human and more-than-human entanglements with both methods and data.

\section{Fluid methodological spaces and vital inquiry}

My intention for this paper was a wider exploration into how a posthuman, post-qualitative methodology could be conceptualized as a methodological umbra and entangled in a doctoral research inquiry. The notion of human intention is a problematic concept within a flat ontology. May (2005) discusses the random nature of assemblages where bodies connect and coalesce in chance meetings, intentionality therefore cannot be presupposed. However, this paper has afforded me the space to map and experiment with (a)(my) methodology. The wider question was 'How might a methodology live?' and I have entered and plugged into the umbra, being affected by and becomingwith-methodology. The umbra is a complex, fluid, multiple, vital, and dynamic process which not only describes the seductiveness of traditional qualitative research but also explores the conditions of possibility and reveals how a 'living' methodology might be co-constituted within anarchic smooth space. In one instance, the umbra is the pull of traditional qualitative research methodology and methods which seek to fix and stratify methodology foreclosing new possibilities. In another it is the unsettledness, which manifest during entanglements with the unique and connected components of post-qualitative inquiry opening new and creative ways of thinking/doing/seeing inquiry. We have seen how Deleuze and Guattari's (1987) concept of smooth and striated space have been employed to consider the interplay when plugging into and working with(in) the umbra. Furthermore, the fluid nature of posthuman, post-qualitative inquiry has been explored, which highlights how complexity 
flows within and between aspects of the research assemblage promoting vital and dynamic ways of exploring the 'living' methodology.

The posthuman project is concerned with a de-centred subject and the human-as-researcher has been re-positioned within post-qualitative inquiry. By viewing the human-as-researcher as a body within the research assemblage human privilege is mediated. All bodies can be considered an equal part within the research assemblage and researcher diaries can be used as vital data to be plugged into wider theoretical conceptions. I have demonstrated that a fluid methodological approach allows for the development of a map not a tracing (Deleuze and Guattari, 1987) of methodology, data, and methods. The map, not fixed and immutable but ephemeral, shadowy, and micro-political, where connections between data, researcher, methods, and methodology are made, unmade, and remade as the assemblage is in flux. Data has been problematized and consideration has been given to whether data is revealed by chance happenings when 'the future actualized is largely out of control of any particular person or group of people' (May, 2005: 63), and although bodies are not passive recipients they cannot shape the assemblage. Furthermore, the deterritorialization of data has seen a widening of the possible nature of data. Drawing on Koro-Ljungberg (2013), Pink (2015) and St. Pierre (1997) and plugging into the umbra data is revisited to consider the affective flows between human, non-human and more-than-human. The nature of methods has been explored and taking a lead from Springgay (2015) I have thought differently about how affect and bodies can influence the conceptualizations of method. This affective response to methods allows for a review of what methods produce, and how the diversity of methods can intensify the flows revealing wider data entanglements. I concur with Springgay (2015) that in my research new methods may not be required but what is required is an openness to new ways of activating and thinking methods to explore the flows within and between assemblages.

The methodological umbra is a way to explore the unsettledness, shadows, and new conditions of possibility for a 'living' inquiry with the spaces constituted and produced within (doctoral) research. By plugging into the umbra a dialogue can be entered regarding how life might become more productive. I have demonstrated that becoming-researcher, becoming-methodology, becoming-data sees relational and co-constitutive entanglements within the research assemblage. Here the interplay between smooth and striated space reveals absolute and relative movements as normative qualitative research and post-qualitative research impact on the researcher. The methodological umbra is still productive in my work, and the assemblage is still fluid and connective as the doctoral research detailed in this paper remains unfinished: a methodological future unknown but vitally productive and in movement.

\section{Acknowledgements}

This paper has developed from a conference presentation given at the Gender, Work and Organization (GWO) 9th Biennial International Interdisciplinary conference, Keele, United Kingdom, July 2016 as part of the stream 'Post-qualitative' methodologies (of difference). I would like to thank the stream conveners, co-presenters, and audience for this wider engagement, which helped push forward my affective relations with methodology and unknotted some of the knots that stratified my thinking. I would also like to thank my doctoral supervisors Professors Janet McCray, Ben Noys and Vini Lander, the Editors of Reconceptualizing Educational Research Methodology, and feedback from the anonymous reviewers for their encouragement to continue with a posthuman entanglement. 


\section{References}

Barad, K. (2007). Meeting the Universe Halfway. Quantum Physics and the Entanglement of Matter and Meaning. Durham: Duke University Press. http://dx.doi.org/10.1215/9780822388128

Baugh, B. (2010). 'Body' in A. Parr (Ed.), The Deleuze Dictionary, revised edition. Edinburgh: Edinburgh University Press, pp. 35-37.

Bennett, J. (2010). Vibrant Matter: a political ecology of things. Durham, N.C.: Duke University Press.

Benozzo, A., Bell, H. and Koro-Ljungberg, M. (2013). 'Moving Between Nuisance, Secrets, and Splinters as Data', Cultural Studies $\leftrightarrow$ Critical Methodologies, 13(4), 309-315. http://dx.doi.org/10.1177/1532708613487878

Bertram, T. and Pascal, C. (2014). Early Years Literature Review. CREC and Early Education. Available from https://www.early-education.org.uk/early-years-literature-review (Accessed 30 July 2016).

Biesta, G. (2007). 'Why "what works" won't work: Evidence based practice and he democratic deficit in education', Educational Theory, 57(1), 1-22. http://dx.doi.org/10.1111/j.17415446.2006.00241.x

Bloch, M. N., Swadener, B. B. and Canella, G. S. (eds.) (2014). Reconceptualizing Early Childhood Education - A Reader - Critical Questions, New Imaginaries and Social Activism. New York: Peter Lang.

Bonta, M. and Protevi, J. (2004). Deleuze and Geophilosophy: A Guide and Glossary. Edinburgh: Edinburgh University Press.

Carlson, D. (2015). 'Forward' in N. Snaza and J. A. Weaver (eds.) Posthumanism and Educational Research. New York: Routledge, pp. viiii-xii.

Cohen, L., Manion, L and Morrison, K. (2011). Research Methods in Education $7^{\text {th }}$ Edition. Abingdon: Routledge.

Coole, D. H. and Frost, S. (2010). (eds.) New Materialisms: Ontology, agency, and politics. Durham, NC: Duke University Press.

Cumming, T. (2015). 'Challenges of 'thinking differently' with Rhizoanalytic approaches: a reflexive account', International Journal of Research \& Method in Education, 38(2), 137-148. http://dx.doi.org/10.1080/1743727X.2014.896892

Dahlberg, G., Moss, P. and Pence, A. (2013). Beyond Quality in Early Childhood Education and Care, Languages of Evaluation $3^{\text {rd }}$ Ed. Abingdon: Routledge.

DeLanda, M. (2002). Intensive Science and Virtual Philosophy. London: Continuum.

Deleuze, G. (1990). The Logic of Sense. Trans, by M. Lester. New York: Columbia University Press.

Deleuze, G. (1992). Postscripts on the Society of Control, October, 59: 3-7.

Deleuze, G. (1994). Difference and repetition. London: Athalone Press.

Deleuze G. (1997). Essays critical and clinical. Minneapolis: University of Minnesota Press.

Deleuze, G. and Guattari, F. (1987). A Thousand Plateaus: Capitalism and Schizophrenia. London: Bloomsbury Academic. 
Department for Education (2013). Teachers' Standards (Early Years). Crown Copyright. Available from https://www.gov.uk/government/uploads/system/uploads/attachment_data/file/211646/E arly_Years_Teachers_Standards.pdf (Accessed 24 January 2015).

Department for Education (2014). Statutory Framework for the Early Years Foundation Stage: Setting the standards for learning, development and care for children from birth to five. Cheshire: Department for Education.

Fox, N. J. and Alldred, P. (2015a). 'New materialist social inquiry: designs, methods and the researchassemblage', International Journal of Social Research Methodology, 18(4), 399-414. http://dx.doi.org/10.1080/13645579.2014.921458

Guttorm, H., Hohti, R., and Paakkari, A. (2015). " "Do the next thing”: an interview with Elizabeth Adams St. Pierre on post-qualitative methodology', Reconceptualizing Educational Research Methodology, 6(1), 15-22. http://dx.doi.org/10.7577/rerm.1421

Honan, E. and Bright, D. (2016). 'Writing a thesis differently', International Journal of Qualitative Studies in Education, 29(5), 731-743. http://dx.doi.org/10.1080/09518398.2016.1145280

Holbrook, T. and Pourchier, N. M. (2012). 'The Exquisite Corpse of A/r/t: Bodied Troublings of Qualitative Research as Usual', Visual Arts Research, 38(2), 41-55. http://dx.doi.org/10.5406/visuartsrese.38.2.0041

Holmes, R. and Jones, L. (2013). 'Flesh, Wax, Horse Skin, and Hair: The Many Intensities of Data', Cultural Studies $\leftrightarrow$ Critical Methodologies, 13(4), 357-372. http://dx.doi.org/10.1177/1532708613487883

Holmes, R. and Jones, L. (2016). 'Flickering, Spilling and Diffusing Body/Knowledge in the Posthuman Early Years' in C.A. Taylor and C. Hughes (eds.) Posthuman Research Practices in Education. London: Palgrave Macmillan, pp. 108-127. http://dx.doi.org/10.1057/9781137453082_8

Jackson, A. Y. and Mazzei, L. (2009). Voice in Qualitative Inquiry. Challenging conventional, interpretive, and critical conceptions in qualitative research. Abingdon: Routledge.

Jackson, A. Y. and Mazzei, L. (2012) Thinking with Theory in Qualitative Research. Viewing data across multiple perspectives. Abingdon: Routledge.

Jackson, A. Y. and Mazzei, L. (2013). 'Plugging One Text Into Another: Thinking With Theory in Qualitative Research', Qualitative Inquiry, 19(4), 261-271.

http://dx.doi.org/10.1177/1077800412471510

Jones, L. and Holmes, R. (2014). 'Studying Play through New Research Practices' in L. Booker, M. Blaise and S. Edwards (eds.) SAGE Handbook of Play and Learning. London: Sage, pp. 128139. http://dx.doi.org/10.4135/9781473907850.n13

Jones, L., Osgood, J., Holmes, R. and Urban, M. (2016). 'Reimagining quality in early childhood', Contemporary Issues in Early Childhood, 17(1), 3-7. http://dx.doi.org/10.1177/1463949115627912

Koro-Ljungberg. M. (2012). 'Methodology is Movement is Methodology' in S. R. Steinberg and G. S. Canella (eds.) Critical Qualitative Research Reader. New York: Peter Lang Publishing Inc., pp. 82-90. 
Koro-Ljungberg, M. (2013). “'Data” as Vital Illusion', Cultural Studies $\leftrightarrow$ Critical Methodologies, 13(4), 274-278. http://dx.doi.org/10.1177/1532708613487873

Koro-Ljungberg, M. (2016). Reconceptualizing Qualitative Research: Methodologies without Methodology. London: Sage.

Koro-Ljungberg, M. and Mazzei, L. (2012). 'Problematizing methodological simplicity in qualitative research: Editors introduction', Qualitative Inquiry, 18(9), 726-729.

http://dx.doi.org/10.1177/1077800412453013

Lather, P. and St. Pierre, E. A. (2013). 'Post-qualitative research', International Journal of Qualitative Studies in Education, 26(6), 629-633. http://dx.doi.org/10.1080/09518398.2013.788752

Lenz Taguchi, H. (2010). Going Beyond the Theory/Practice Divide in Early Childhood Education: Introducing an Intra-Active Pedagogy. Abingdon: Routledge.

Livesey, G, (2010). 'Assemblage' in A. Parr (ed.), The Deleuze Dictionary, revised edition. Edinburgh: Edinburgh University Press, pp. 18-19.

Longhurst, R. (2001). Bodies. Exploring Fluid Boundaries. Abingdon Routledge. http://dx.doi.org/10.4324/9780203193600

MacLure, M. (2011). 'Qualitative Inquiry: Where are the Ruins?' Qualitative Inquiry, 17(10), 9971005. http://dx.doi.org/10.1177/1077800411423198

MacLure, M. (2013). 'Classification or Wonder? Coding as an Analytical Practice in Qualitative Research' in R. Coleman and J. Ringrose (eds.) Deleuze and Research Methodology. Edinburgh: Edinburgh University Press, pp. 164-183.

Manning, E. (2007). Politics of Touch: Sense, Movement, Sovereignty. Minneapolis: University of Minnesota Press.

Manning, E. (2013). Always More Than One: Individuations Dance. Durham, NC: Duke University Press.

Massumi, B. (2002). Parables for the Virtual. Durham, NC: Duke University Press. http://dx.doi.org/10.1215/9780822383574

Massumi, B. (2015). Politics of Affect. Cambridge: Polity Press.

May. T, (2005). Gilles Deleuze: An Introduction. Cambridge University Press: Cambridge. http://dx.doi.org/10.1017/CBO9781139165419

Moss, P. (2014). Transformative Change and Real Utopias in Early Childhood Education: A story of democracy, experimentation and potentiality. Abingdon: Routledge.

Olsson, L. M. (2009). Movement and experimentation in young children's learning: Deleuze and Guattari in early childhood education. Abingdon: Routledge.

Osgood, J. (2012). Narratives from the Nursery: Negotiating professional identities in early childhood. Abingdon, Routledge.

Osgood, J. \& Scarlet, R.R./Giugni, M. (2015). 'Putting post humanist theory to work to reconfigure gender in early childhood: when theory becomes method becomes art'. Global Studies in Childhood, 5(3), 346 - 360. http://dx.doi.org/10.1177/2043610615597160 
Otterstad, A. M. and Waterhouse, A. L. (2015). 'Beyond regimes of signs: making art/istic portrayals of haptic moments/movements with child/ren/hood'. Discourse Studies in the Cultural Politics of Education, 37(5), 739-753. http://dx.doi.org/10.1080/01596306.2015.1075727

Pink, S. (2015). Doing sensory ethnography $2^{\text {nd }} E d$. London: Sage.

Ross, A. (2010). 'Desire' in A. Parr (ed.), The Deleuze Dictionary, revised edition. Edinburgh: Edinburgh University Press, pp. 65-67.

Silverman, D. (2011). Interpreting Qualitative Data $4^{\text {th }}$ Edition. London: Sage.

Snaza, N. and Weaver, J. A. (2015). 'Introduction - Education and the Posthumanist Turn' in N. Snaza and J. A. Weaver (eds.) Posthumanism and Educational Research. New York: Routledge, pp. $1-14$.

Springgay, S. (2015). “'Approximate-Rigorous Abstractions” Propositions of Activation for Posthumanist Research in Education' in N. Snaza and J. A. Weaver (eds.) Posthumanism and Educational Research. Abingdon: Routledge, pp. 76-88.

Smith, D. W. (1997). 'Introduction' in G. Deleuze Essays critical and clinical. Minneapolis: University of Minnesota Press, pp. xi-iiii.

St. Pierre, E. A. (1997). Methodology in the fold and the irruption of transgressive data, Qualitative Studies in Education, 10(2), 175-189. http://dx.doi.org/10.1080/095183997237278

St. Pierre, E. A. (2013). 'The posts continue: becoming', International Journal of Qualitative Studies in Education, 26(6), 646-657. http://dx.doi.org/10.1080/09518398.2013.788754

St. Pierre, E. A. (2016a). 'Rethinking the Empirical in the Posthuman' in C.A. Taylor and C. Hughes (eds.) Posthuman Research Practices in Education. London: Palgrave Macmillan, pp. 25-36. http://dx.doi.org/10.1057/9781137453082_3

St. Pierre, E. A. (2016b). 'The Empirical and the New Empiricisms', Cultural Studies $\leftrightarrow$ Critical Methodologies, 16 (2), 99-110.

St. Pierre, E. A., Jackson, A. Y. and Mazzei, L. A. (2016). 'New empiricisms and New Materialism: Conditions for New Inquiry', Cultural Studies $\leftrightarrow$ Critical Methodologies, 16(2), 111-124.

Taylor, C. A. (2016). 'Edu-crafting a Cacophonous Ecology: Posthuman Research Practices for Education' in C.A. Taylor and C. Hughes (eds.) Posthuman Research Practices in Education. London: Palgrave Macmillan, pp. 5-24. http://dx.doi.org/10.1057/9781137453082_2

Taylor, C. A. and Hughes, C. (eds.) (2016). Posthuman Research Practices in Education. London: Palgrave Macmillan. http://dx.doi.org/10.1057/9781137453082

Waldfogel, J. (2004). Social mobility, life chances and the Early Years. CASE paper 88, LSE, London. Available from http://papers.ssrn.com/sol3/papers.cfm?abstract_id=1159319 (Accessed 30 July 2016). 